\title{
PENERAPAN PEMBELAJARAN PENGAJUAN MASALAH BERBANTUAN PAPAN MAGNETIK UNTUK MENINGKATKAN PEMAHAMAN OPERASI HITUNG BILANGAN BULAT
}

\author{
Choirun Ulfanisa ${ }^{1}$, Tatag Yuli Eko Siswoyo ${ }^{2}$, Rooselyna Ekawati ${ }^{3}$ \\ ${ }^{1}$ Mahasiswa Program Pascasarjana, Prodi Pendidikan Dasar, Universitas Negeri Surabaya, \\ ${ }^{2 \& 3}$ Dosen Pascasarjana, Prodi Pendidikan Dasar, Universitas Negeri Surabaya \\ e-mail: ${ }^{1}$ choirunulfa@gmail.com
}

\section{Received : $\quad$ Maret 2018}

Reviewed: April 2018

Accepted : Mei 2018

Published : Mei 2018

\section{ABSTRACT}

This research is aimed to improve student's understanding in integer arithmetic operations through the application of learning to use problem posing with magnetic board media in $4^{\text {th }}$ grade student SDN Bangsal 4 Kediri City. This research was conducted in two cycles, cycle I and cycle 2. Each cycle consisted of two meetings which the student's activity do problem posing with magnetic board. Research data show an increase student's understanding on integer arithmetic operations. This achievement can be seen from the class average value of the final test cycle I at 76,75 with classical completeness $72,5 \%$ and the class average value of final test second cycle of 82,13 with classical completeness $85 \%$. Students response to the problem posing learning with the help of a magnetic board in this research were very positive. This is evident from the results of the student questionnaire consisting of 8 statement and all of them gained very positive criteria of students. Problems were found during a lesson using a problem posing with magnetic board media especially student take a long time to create questions or in examining the matter and the results of the answers that the student. Based on the analysis of data can be concluded that the problem posing learning with the magnetic board media effective to enhance student's understanding class IV SDN Bangsal 4 Kediri City.

Keywords: Problem Posing, Magnetic Board Media, Understanding, Student Response.

\section{ABSTRAK}

Penelitian ini bertujuan untuk meningkatkan pemahaman siswa terhadap operasi hitung bilangan bulat melalui penerapan pembelajaran menggunakan pengajuan masalah dengan media papan magnetik pada siswa kelas IV SDN Bangsal 4 Kota Kediri. Penelitian ini dilaksanakan dalam dua siklus, yaitu siklus I dan siklus II, masing-masing siklus terdiri dari dua pertemuan dimana kegiatan siswa melakukan pengajuan masalah dengan bantuan papan magnetik. Data hasil penelitian menunjukkan adanya peningkatan pemahaman siswa pada operasi hitung bilangan bulat. Pencapaian ini dapat dilihat dari rata-rata kelas nilai tes akhir siklus I sebesar 76,75 dengan ketuntasan klasikal sebesar $72,5 \%$ dan rata-rata kelas nilai tes akhir siklus II sebesar 82,13 dengan ketuntasan klasikal sebesar 85\%. Respon siswa terhadap pembelajaran dengan model pengajuan masalah dengan bantuan papan magnetik dalam penelitian ini sangat positif. Hal ini terlihat dari hasil angket siswa yang terdiri dari 8 pernyataan dan semuanya memperoleh kriteria sangat positif dari siswa. Kendala yang ditemukan pada saat pembelajaran menggunakan pengajuan masalah dengan media papan magnetik terutama siswa membutuhkan waktu yang lama dalam membuat soal ataupun dalam memeriksa soal dan hasil jawaban yang dibuat siswa. Berdasarkan hasil analisis data, dapat disimpulkan bahwa pembelajaran pengajuan masalah dengan media papan magnetik efektif untuk meningkatkan pemahaman siswa Kelas IV SDN Bangsal 4 Kota Kediri.

Kata Kunci: Pembelajaran Pengajuan Masalah, Media Papan Magnetik, Pemahaman, Respon Siswa. 


\section{PENDAHULUAN}

Salah satu tujuan mata pelajaran matematika adalah agar siswa memiliki pemahaman matematik. Kemampuan pemahaman matematik sangat penting untuk dikembangkan sejak jenjang sekolah dasar karena akan menjadi dasar untuk mengembangkan kemampuan seperti kemampuan mengaplikasikan konsep matematik, penalaran matematik, berpikir kritis, dan pemecahan masalah. Hal ini sejalan dengan Wiharno (dalam Ompusunggu, 2009) yang menyimpulkan bahwa "kemampuan pemahaman matematik merupakan suatu kekuatan yang harus diperhatikan dan diperlakukan secara fungsional dalam proses dan tujuan pembelajaran, hal tersebut hanya bisa dilakukan melalui pembelajaran dengan pemahaman". Akan tetapi agar siswa bisa memahami konsep matematika tidaklah mudah. Hal ini disebabkan karena siswa biasanya belajar matematika dengan cara menghafal bukan memahami, materi yang bersifat abstrak membuat siswa kesulitan dalam memahaminya, serta anggapan siswa bahwa matematika merupakan pelajaran yang sulit membuat mereka malas untuk mempelajari dan memahaminya.

Operasi hitung bilangan bulat merupakan salah satu kompetensi bagi siswa kelas IV, V, dan VI. Jika melihat bahwa operasi hitung bilangan bulat sudah diberikan sejak kelas IV, seharusnya di kelas V dan VI siswa sudah memiliki kemampuan pemahaman matematik untuk materi ini. Sebagian besar siswa tidak memahami cara menghitung operasi hitung bilangan bulat yang seharusnya diselesaikan dengan cara dikurangi tetapi justru dijumlahkan atau sebaliknya, yang seharusnya hasilnya positif tetapi justru negatif. Hal ini menunjukkan bahwa ternyata meskipun materi operasi hitung bilangan bulat sudah diajarkan di tiga tingkatan kelas tetapi pemahaman siswa masih kurang.

Pemahaman siswa terhadap pelajaran matematika tentunya sangat dipengaruhi oleh model yang digunakan guru dalam mengajar. Kebanyakan guru mengajar dengan pembelajaran yang masih terfokus pada guru sebagai sumber utama pengetahuan kemudian ceramah adalah yang menjadi pilihan utama strategi belajar yang menyebabkan rasa bosan untuk belajar matematika. Slameto (2015) mengungkapkan bahwa "Guru biasanya mengajar dengan metode ceramah saja sehingga siswa menjadi bosan, mengantuk, pasif, dan hanya mencatat saja".

Upaya untuk mengatasi masalah tersebut banyak cara yang dapat dilakukan guru dalam mengajarkan bilangan bulat, salah satunya dengan pembelajaran pengajuan masalah yang dalam Bahasa Inggrisnya yaitu problem posing. "Pengajuan soal intinya meminta siswa untuk mengajukan atau membuat masalah (soal) baru sebelum, selama atau sesudah menyelesaikan masalah awal yang diberikan" (Siswono, 2005, p. 3) . Amri (2013) menyatakan bahwa "pada prinsipnya, model pembelajaran problem posing mewajibkan siswa untuk mengajukan soal sendiri melalui belajar soal dengan mandiri”. Sejalan dengan pendapat tersebut, Kasiati (dalam Ompusunggu, 2007) menyatakan bahwa "salah satu strategi pembelajaran adalah dengan menggunakan model problem posing, yakni menekankan peserta didik untuk membuat soal". Informasi yang ada diolah dalam fikiran, dan setelah paham siswa akan dapat membuat masalah (soal) sehingga mengakibatkan terbentuknya pemahaman yang lebih mantap pada diri siswa. Silver (1994) menyatakan bahwa "di Amerika, misalnya, baru-baru ini melaporkan seperti kurikulum dan standar evaluasi untuk sekolah matematika (NCTM, 1989) dan standar profesional untuk mengajar matematika (NCTM, 1991) telah menyerukan peningkatan penggunaan problem posing di kelas matematika". Hal ini menunjukkan bahwa model pembelajaran pengajuan masalah ini sangat efektif untuk membentuk pemahaman matematik seperti pernyataan Silver (1994) bahwa "Problem posing sebagai jendela untuk pemahaman matematik siswa".

Penerapan suatu model pembelajaran harus memiliki langkah-langkah yang jelas, hal tersebut sangat berpengaruh terhadap pembelajaran. Amri (2013) menyatakan bahwa langkah-langkah model pembelajaran problem posing yaitu: 1) Guru menjelaskan materi pelajaran, alat peraga yang disarankan, 2) memberikan latihan soal secukupnya, 3) siswa mengajukan soal yang menantang dan dapat menyelesaikan, ini dilakukan dengan kelompok, 4) pertemuan berikutnya guru meminta siswa menyajikan soal temuan di depan kelas, 5) guru memberikan tugas rumah secara individual.

Berdasarkan beberapa pendapat yang telah dikemukakan, peran guru dalam model pembelajaran pengajuan masalah (problem posing) adalah sebagai fasilitator yaitu menyiapkan alat peraga maupun media yang sesuai dengan materi yang dibahas. Siswa Sekolah Dasar umurnya berkisar antara 6 atau 7 tahun sampai 12 atau 13 tahun, sesuai dengan pendapat Piaget (dalam Heruman, 2011) menjelaskan bahwa "mereka berada pada fase operasional konkret". Kemampuan yang tampak pada fase ini adalah kemampuan dalam proses berfikir untuk mengoperasikan kaidah-kaidah logika, meskipun masih terikat dengan objek yang bersifat konkret. Benda-benda fisik atau manipulatif untuk memodelkan konsep-konsep matematika merupakan alat-alat yang penting untuk membantu siswa belajar matematika (Walle, 2006, p.31). 
Berkaitan dengan hal tersebut, tujuan penggunaan alat peraga adalah untuk mendemonstrasikan konsep yang abstrak ke dalam bentuk visual sehingga penyampaian materi menjadi lebih maksimal.

Untuk mengenalkan konsep operasi hitung pada sistem bilangan bulat dapat dilakukan melalui 3 tahap, yaitu: 1) tahap pengenalan konsep secara konkret, 2) tahap pengenalan konsep secara semi konkret atau semi abstrak, 3) tahap pengenalan konsep secara abstrak (Muhsetyo et al., 2014, p.3.10). Pada tahap pertama model peragaan yang dapat dikembangkan yaitu menggunakan pendekatan himpunan (yaitu menggunakan alat peraga manik-manik). Peneliti akan membuat pin dari magnet dan menggunakan papan magnetik sebagai media untuk memeragakannya. Alat peraga pin magnet dipilih karena dapat memberi pemahaman atau memanipulasi objek-objek konkret secara langsung dan diperagakan dengan papan magnetik. Penggunaan alat peraga ini salah satu tujuannya adalah untuk pemahaman.

Penulis ingin mengetahui bagaimana penerapan pembelajaran pengajuan masalah berbantuan media papan magnetik dapat meningkatkan pemahaman operasi hitung bilangan bulat siswa Kelas IV SD. Penelitian ini bermanfaat: (1) Bagi guru, dapat mengetahui penerapan model pembelajaran pengajuan masalah (problem posing) berbantuan media papan magnetik sebagai salah satu variasi dalam mengajarkan operasi hitung bilangan bulat untuk meningkatkan pemahaman siswa di Kelas IV dan (2) Bagi peneliti lain, sebagai sumber informasi untuk mengadakan penelitian lebih lanjut, khususnya mengenai pembelajaran matematika model pembelajaran pengajuan masalah berbantuan media papan magnetik.

\section{TINJAUAN PUSTAKA}

Problem posing adalah istilah dalam Bahasa Inggris yaitu dari kata "Problem" artinya masalah, soal, atau persoalan dan kata "to pose" yang artinya mengajukan. Problem posing bisa diartikan sebagai pengajuan soal atau pengajuan masalah.

Thobroni dan Mustofa (2012) menyatakan bahwa model pembelajaran problem posing adalah suatu model pembelajaran yang mewajibkan para siswa untuk mengajukan soal sendiri melalui belajar soal (berlatih soal) secara mandiri. Sedangkan menurut Suryanto dalam Cakheppy (2011) mengartikan bahwa kata "problem" sebagai masalah atau soal, sehingga pengajuan masalah dipandang sebagai suatu tindakan merumuskan masalah atau soal dari situasi yang diberikan.

Berdasarkan beberapa pendapat yang telah dikemukakan, bahwa langkah-langkah problem posing adalah siswa mengajukan dan menjawab soal dengan berkelompok berdasarkan penjelasan guru ataupun pengalaman siswa itu sendiri. Maka, langkah- langkah yang digunakan adalah:

a. Menjelaskan materi pelajaran dengan media dan alat peraga yang telah disediakan,

b. Memberikan latihan soal,

c. Membagi siswa menjadi kelompok secara heterogen,

d. Secara berkelompok, siswa mengajukan pertanyaan pada lembar soal,

e. Menukarkan lembar soal pada kelompok lainnya,

f. Menjawab soal pada lembar jawab, dan

g. Mempresentasikan lembar soal dan lembar jawab di depan kelas.

Ada beberapa manfaat pendekatan pengajuan masalah (problem posing) antara lain sebagai berikut: Membantu siswa dalam mengembangkan keyakinan dan kesukaan terhadap matematika, sebab ide-ide matematika siswa dicobakan untuk memahami masalah yang sedang dikerjakan dan dapat menguatkan performannya dalam pemecahan masalah (English dalam Siswono, 2008). (b) Pengajuan masalah dapat membantu guru tidak hanya jendela untuk melihat pemahaman siswa, tetapi juga sebagai cermin yang dapat merefleksikan isi dan karakter dari pengalaman belajar matematika di sekolahnya. (Silver, 1994). (c) Pengajuan masalah dapat berpengaruh positif terhadap kemampuan siswa untuk memecahkan masalah. (Silver dan Leung dalam Christouet.al, 2005). (d) Menurut English (dalam Christou et al, 2005:), problem posing dapat meningkatkan kemampuan berpikir, kemampuan memecahkan masalah, sikap serta kepercayaan diri siswa dalam menyelesaikan masalah dan secara umum berkontribusi terhadap pemahaman konsep matematika. (e) Menurut Akay dan Boz (2010) problem posing mendorong tumbuhnya keyakinan dan sikap positif siswa terhadap pelajaran matematika. (f) Menurut Singer, et al (dalam Walkington, 2015) Problem posing dapat meningkatkan keterampilan pemecahan masalah, sikap, dan kepercayaan diri dalam matematika, dan memberikan kontribusi untuk pemaham konsep matematika dan pengembangan pemikiran matematis. (g) Menurut Bonotto (2010) bahwa problem posing memberikan pengaruh positif kepada siswa di antaranya cakap dalam menyelesaikan masalah dan menyediakan sebuah kesempatan untuk memperoleh pengetahuan dan pemahaman konsep dan proses matematika siswa. (h) Pengajuan soal juga merangsang peningkatan kemampuan matematika siswa. Sebab dalam mengajukan soal siswa perlu membaca suatu informasi yang diberikan dan mengkomunikasikan pertanyaan secara verbal maupun tertulis (Siswono, 2000).

Sedangkan kelemahan pengajuan masalah sebagaimana diungkapkan oleh Siswomo (1999) adalah sebagai berikut: (a) Pembelajaran model problem posing membutuhkan waktu yang lama dan (b) Agar pelaksanaan kegiatan dalam membuat soal dapat dilakukan dengan baik perlu ditunjang oleh buku-buku yang dapat dijadikan pemahaman dalam kegiatan belajar terutama membuat soal. 
Papan magnetik lebih dikenal sebagai white board atau magnetic board adalah sebilah papan yang dibuat dari lapisan email putih pada sebidang logam, sehingga pada permukaannya dapat ditempelkan benda-benda yang ringan dengan interaksi magnet (Daryanto, 2016, p. 23).

Penggunaan media papan magnetik untuk operasi hitung bilangan bulat ini membutuhkan alat peraga berupa pin magnet. Alat peraga pin magnet pendekatannya menggunakan konsep himpunan. Kita dapat menggabungkan atau memisahkan dua himpunan yang dalam hal ini anggotanya berbentuk pin magnet. Pin magnet dibuat dalam dua warna, satu warna untuk menandakan bilangan positif (merah), sedangkan warna lainnya untuk menandakan bilangan negatif (biru). Dalam alat ini, bilangan nol (netral) diwakili oleh dua buah pin dengan warna berbeda. Bentuk netral ini dipergunakan pada saat kita akan melakukan operasi pengurangan $a-b$ dengan $b>a$ atau $b<0$. Selanjutnya, dalam menggunakan alat peraga ini (dalam hal ini untuk melakukan operasi hitung penjumlahan dan pengurangan) harus memperhatikan beberapa prinsip kerjanya (Muhsetyo, 2014, p.3.12), yaitu: dalam operasi hitung, proses penggabungan dalam konsep himpunan diartikan sebagai penjumlahan, sedangkan proses pemisahan dapat diartika sebagai pengurangan.

\section{METODE}

Jenis penelitian ini adalah penelitian tindakan kelas, yang desainnya mengacu pada model Kemmis dan Mc. Taggart terdiri atas empat tahap yaitu perencanaan, pelaksanaan tindakan, observasi dan refleksi. Dalam penelitian ini, peneliti adalah instrumen utama karena peneliti yang merencanakan, merancang, melaksanakan, mengumpulkan data, menganalisis data, menarik kesimpulan, dan membuat laporan. Penelitian ini dilakukan pada semester II Tahun Pelajaran 2016/2017. Subjek penelitian ini adalah 40 siswa Kelas IV SDN Bangsal 4 Kota Kediri yang meliputi 23 siswa laki-laki dan 17 siswa perempuan.

Jenis data dalam penelitian ini berupa data kuantitatif yaitu data yang diperoleh dari tes yang diberikan kepada siswa. Untuk melengkapi data kuantitatif digunakan data kualitatif yang diperoleh dari hasil observasi guru dan juga siswa maupun angket siswa.

Instrumen yang digunakan dalam penelitian ini adalah dengan menggunakan lembar observasi pada saat proses pembelajaran berlangsung. Bentuk tes tertulis digunakan untuk mengetahui tingkat pemahaman siswa apakah telah mencapai target ketuntasan. Instrumen lainnya yaitu berupa ngket untuk mengetahui respon siswa terhadap penerapan pembelajaran.

Untuk teknis analisis sebagai berikut:

\section{a) Analisis Data Hasil Tes}

Teknik analisis hasil evaluasi untuk mengetahui ketuntasan belajar baik secara individual maupun secara klasikal dengan cara menganalisis data hasil tes menggunakan kriteria ketuntasan belajar. Persentasehasil tes kemudian dibandingkan dengan KKM (Kriteria Ketuntasan Minimal) yang telah ditentukan. Menghitung hasil tes dengan cara membandingkan jumlah skor yang diperoleh siswa dengan jumlah skor maksimum kemudian dikalikan $100 \%$. Berikut rumus perhitungan persentase hasil tes siswa:

$$
\text { Persentase hasil belajar }=\frac{\sum \text { Skor yang dicapai }}{\sum \text { Skor maksimum }} \times 100 \%
$$

Adapun teknik analisis yang digunakan untuk mengetahui peningkatan pada penelitian ini, yakni dengan membandingkan persentase ketuntasan belajar secara klasikal pada penerapan model pengajuan masalah dengan media papan magnetik siklus I dan siklus II. Sedangkan persentase ketuntasan belajar secara klasikal dihitung dengan cara membandingkan banyak siswa yang mencapai ketuntasan belajar dengan banyak siswa secara keseluruhan (siswa maksimal) kemudian dikalikan $100 \%$.Sedangkan rumus untuk menghitung persentase keberhasilan pembelajaran adalah sebagai berikut:

Persentase ketuntasan belajar klasikal $=$

$$
\frac{\sum \text { Siswa yang tuntas }}{\sum \text { Siswa maksimal }} \times 100 \%
$$

b) Analisis Data Penerapan Model Pengajuan Masalah Dengan Media Papan Magnetik

Untuk menetahui penerapan model pengajuan masalah dengan media papan magnetik, maka data yang diperlukan berupa data hasil pengamatan melalui lembar observasi mengenai ketepatan guru dan siswa dalam menerapkan tahapan pembelajaran dengan model pengajuan masalah berdasarkan Rencana Pelaksanaan Pembelajaran dan data dari catatan lapangan. Teknik analisis yang digunakan dengan cara membandingkan persentase keberhasilan tindakan guru dalam menerapkan pembelajaran dengan model pengajuan masalah menggunakan media papan magnetik pada sikuls I dan siklus II. Persentase keberhasilan tindakan guru ini dihitung menggunakan rumus sebagai berikut:

$$
\text { Persentase keberhasilan }=\frac{\sum \text { Deskriptor yang muncul }}{\sum \text { Deskriptor maksimal }} \times 100 \%
$$

c) Analisis data angket respon siswa terhadap penerapan model pengajuan masalah dengan media papan magnetik 
Untuk mengetahui respon siswa terhadap penerapan pembelajaran pengajuan masalah dengan media papan magnetik digunakan teknik analisis data sebagai berikut:

Prosentase Rata-Rata (NR) $=\frac{\text { Jumlah Skor }}{\text { Skor Maksimal }} \times 100 \%$

Tindakan pada penelitian ini dikatakan berhasil apabila siswa telah memahami materi penjumlahan dan pengurangan bilangan bulat. Siswa dikatakan paham apabila telah memenuhi indikator keberhasilan pembelajaran yaitu siswa yang tuntas telah mencapai $80 \%$. Keberhasilan tindakan yang dilakukan juga dilihat dari aktivitas guru dalam mengelola pembelajaran di kelas dan aktivitas siswa selama mengikuti pembelajaran dengan menggunakan pembelajaran pengajuan masalah berbantuan media papan magnetik. Aktivitas guru dan aktivitas siswa dalam proses pembelajaran dinilai dalam lembar observasi dan dinyatakan berhasil apabila berada dalam kategori baik atau sangat baik. Selain itu pembelajaran dikatakan berhasil jika respon siswa terhadap pembelajaran adalah positif.

\section{HASIL DAN PEMBAHASAN}

Hasil penelitian ini terbagi dalam dua bagian, yaitu (1) hasil pra tindakan, dan (2) hasil pelaksanaan tindakan. Kegiatan pada pra tindakan yaitu peneliti memberikan tes awal kepada siswa yang diikuti oleh 40 siswa. Tes awal ini bertujuan untuk mengetahui tingkat pengetahuan siswa tentang materi prasyarat dari operasi hitung bilangan bulat dan juga untuk pembentukan kelompok agar heterogen. Materi yang diberikan pada tes awal yaitu pengurangan dan penjumlahan bilangan bulat. Berdasarkan hasil analisis tes awal, diperoleh kesimpulan bahwa sebagian besar siswa belum dapat menjumlahkan dan mengurangkan bilangan bulat positif dan negatif. Hal ini terjadi karena siswa belum memahami konsep bilangan bulat itu sendiri. namun beberapa siswa sudah dapat memahami konsep bilangan bulat serta dapat menyelesaikan operasi hitung penjumlahan dan pengurangan bilangan bulat. Pelaksanaan tindakan dalam penelitian ini terbagi menjadi dua siklus, yaitu siklus I dan siklus II. Setiap siklus terdiri dari dua pertemuan. Kegiatan pada pertemuan pertama, yaitu peneliti memberikan materi penjumlahan bilangan bulat, sedangkan pada pertemuan kedua peneliti materi pengurangan bilangan bulat.

Selama pembelajaran berlangsung dilakukan pengamatan kemampuan guru dan aktivitas siswa. Pengamatan dilakukan oleh dua pengamat. Pembelajaran diakhiri dengan pemberian tes akhir di setiap siklus mengenai materi penjumlahan dan pengurangan pada bilangan bulat untuk mengetahui tingkat pemahaman siswa apakah sudah tuntas kemudian pengisian angket oleh

siswa untuk mengetahui respons mereka terhadap materi operasi hitung bilangan bulat dengan menggunakan pembelajaran pengajuan masalah berbantuan media papan magnetik.

1. Hasil Tes Akhir

Adapun peningkatan hasil belajar pada siklus I dan

II dapat dilihat pada Tabel 1.1 berikut.

Tabel 1. Rekapitulasi Tes Akhir Siklus I dan II

\begin{tabular}{|c|c|c|c|}
\hline No & Nama Siswa & Siklus I & Siklus II \\
\hline 1 & ACR & 60 & 70 \\
\hline 2 & AARMP & 90 & 100 \\
\hline 3 & ARJ & 50 & 90 \\
\hline 4 & AMI & 40 & 60 \\
\hline 5 & $\mathrm{ABP}$ & 70 & 80 \\
\hline 6 & $\mathrm{AF}$ & 95 & 85 \\
\hline 7 & ARAW & 60 & 70 \\
\hline 8 & DFS & 90 & 95 \\
\hline 9 & FPS & 55 & 70 \\
\hline 10 & FCA & 70 & 70 \\
\hline 11 & GE & 65 & 65 \\
\hline 12 & HR & 80 & 95 \\
\hline 13 & HGEP & 80 & 90 \\
\hline 14 & IS & 90 & 85 \\
\hline 15 & IDPL & 80 & 90 \\
\hline 16 & JMW & 90 & 100 \\
\hline 17 & KBB & 95 & 75 \\
\hline 18 & KSD & 80 & 90 \\
\hline 19 & LDR & 80 & 85 \\
\hline 20 & MRH & 100 & 95 \\
\hline 21 & MANS & 100 & 100 \\
\hline 22 & MAA & 80 & 95 \\
\hline 23 & MFP & 65 & 65 \\
\hline 24 & MHS & 100 & 100 \\
\hline 25 & MMA & 15 & 10 \\
\hline 26 & MFM & 85 & 95 \\
\hline 27 & MRH & 70 & 70 \\
\hline 28 & MADL & 90 & 90 \\
\hline 29 & MBR & 70 & 70 \\
\hline 30 & NRM & 100 & 100 \\
\hline 31 & NGA & 85 & 75 \\
\hline 32 & NAP & 50 & 90 \\
\hline 33 & ONN & 50 & 65 \\
\hline 34 & ODL & 90 & 75 \\
\hline 35 & PAW & 100 & 100 \\
\hline 36 & RHAP & 100 & 100 \\
\hline 37 & RFP & 90 & 100 \\
\hline 38 & SYCW & 40 & 40 \\
\hline 39 & ZE & 100 & 90 \\
\hline \multirow[t]{3}{*}{40} & ISD & 70 & 95 \\
\hline & Jumlah & 3070 & 3285 \\
\hline & Rata-rata & 76,75 & 82,13 \\
\hline \multicolumn{2}{|c|}{$\begin{array}{c}\text { Persentase } \\
\text { Ketuntasan Klasikal }\end{array}$} & $72,5 \%$ & $85 \%$ \\
\hline
\end{tabular}


Berdasarkan tes hasil belajar pada gambar di atas menunjukkan bahwa terjadi kemajuan baik pada rata-rata kelas maupun persentase ketuntasan klasikal. Ketuntasan klasikal pada siklus I 72,5\% dan pada siklus II meningkat menjadi $85 \%$.

2. Aktivitas Guru

Tabel 2. Rekapitulasi Hasil Observasi Aktivitas Guru Siklus I dan II

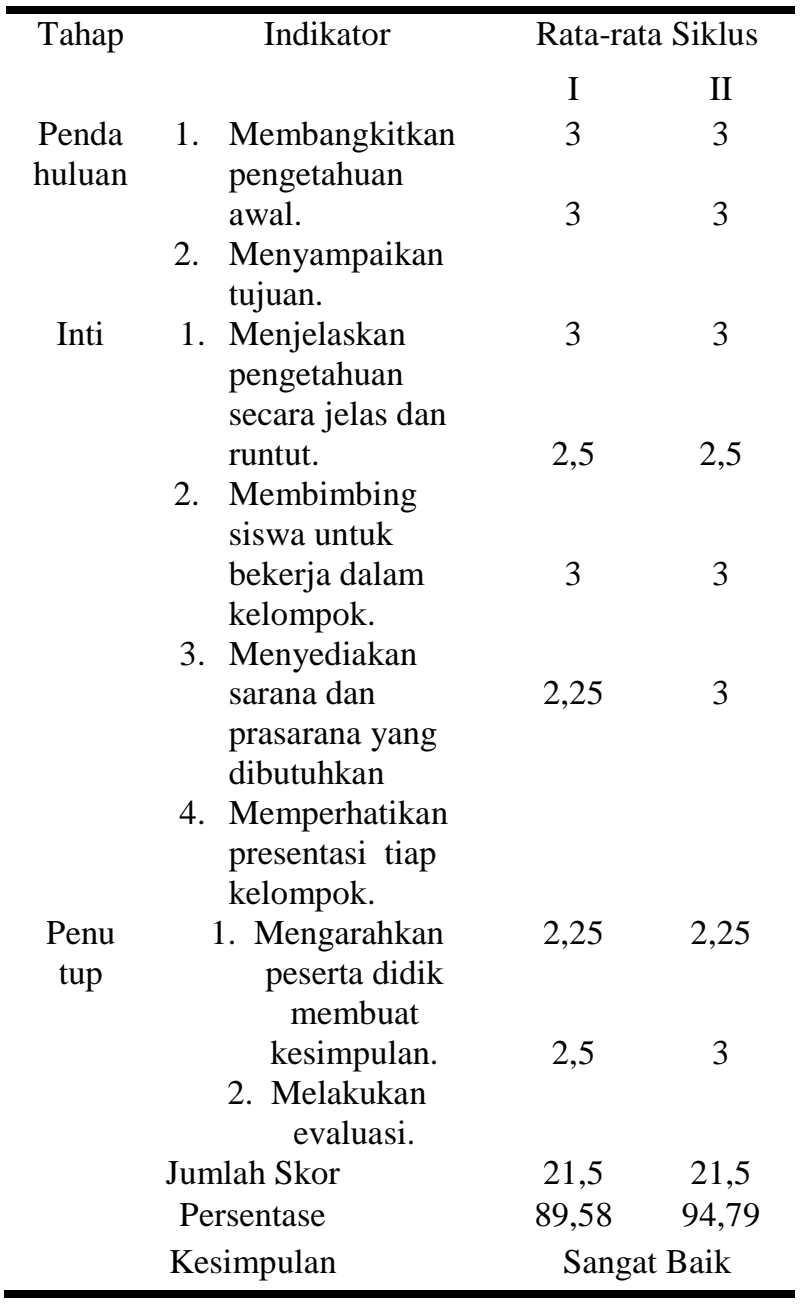

Hasil observasi aktivitas guru pada siklus I maupun siklus II menunjukkan hasil sangat baik.

3. Aktivitas Siswa

Tabel 3. Rekapitulasi Hasil Observasi Aktivitas Siswa Siklus I dan II

\begin{tabular}{|c|c|c|c|}
\hline \multirow[t]{2}{*}{ Tahap } & \multirow[t]{2}{*}{ Indikator } & \multicolumn{2}{|c|}{$\begin{array}{l}\text { Rata-rata } \\
\text { Siklus }\end{array}$} \\
\hline & & I & II \\
\hline $\begin{array}{l}\text { Penda } \\
\text { huluan }\end{array}$ & $\begin{array}{l}\text { 1. Keterlibatan dalam } \\
\text { membangkitkan } \\
\text { pengetahuan awal. }\end{array}$ & 2,25 & 3 \\
\hline & 2. Memperhatikan tujuan. & 2,25 & 2 \\
\hline Inti & $\begin{array}{l}\text { 1. Memperhatikan } \\
\text { penjelasan } \\
\text { pengetahuan. }\end{array}$ & 3 & 3 \\
\hline & 2. Mengerjakan tugas & 3,35 & 3 \\
\hline
\end{tabular}

\begin{tabular}{|c|c|c|c|}
\hline \multirow[t]{8}{*}{ Tahap } & \multirow[t]{2}{*}{ Indikator } & \multicolumn{2}{|c|}{$\begin{array}{l}\text { Rata-rata } \\
\text { Siklus }\end{array}$} \\
\hline & & I & II \\
\hline & $\begin{array}{l}\text { secara berkelompok. } \\
\text { 3elaksanakan } \\
\text { presentasi lembar soal } \\
\text { dan lembar jawab di } \\
\text { depan kelas. }\end{array}$ & 2 & 2,5 \\
\hline & $\begin{array}{l}\text { 1. Membuat kesimpulan } \\
\text { materi. }\end{array}$ & 2,75 & 2,25 \\
\hline & 2. Melakukan evaluasi & 3 & 3 \\
\hline & Jumlah Skor & 17,5 & 18,75 \\
\hline & Persentase & 83,33 & 89,29 \\
\hline & Kesimpulan & Sang & Baik \\
\hline
\end{tabular}

Hasil observasi aktivitas siswa pada siklus I maupun siklus II menunjukkan hasil sangat baik.

4. Respon Siswa

Untuk mengetahui respon siswa terhadap model pembelajaran pengajuan masalah guru membagikan lembar angket respons kepada setiap siswa. Lembar angket berisi 8 pernyataan. Hasil angket respons siswa ini diisi oleh oleh 40 siswa dan hasilnya modus dari semua pernyataan adalah sangat positif.

Selama penelitian berlangsung, terdapat beberapa kelemahan dalam pelaksanaannya diantaranya:

1. Pembelajaran pengajuan masalah merupakan hal yang baru bagi siswa maupun peneliti sehingga peneliti belum memiliki keahlian khusus dan belum maksimal dalam mengarahkan siswa mengajukan masalah.

2. Pembelajaran pengajuan masalah memerlukan waktu yang lama dalam pembuatan soal ataupun dalam memeriksa soal dan hasil jawaban yang dibuat siswa.

\section{SIMPULAN DAN SARAN}

Penerapan pembelajaran pengajuan masalah dengan bantuan papan magnetik dapat meningkatkan pemahaman siswa dalam operasi hitung bilangan bulat siswa Kelas IV SDN Bangsal 4 yang terlihat dari semakin meningkatnya hasil belajar siswa pada siklus II dibanding dengan siklus I. Rata-rata hasil tes pada siklus I yaitu 76,75 dengan ketuntasan klasikal 72,5\% (29 anak) dan rata-rata pada siklus II yaitu 82,13 dengan ketuntasan klasikal 85\% (34 anak). Penerapan pembelajaran pengajuan masalah yang dilaksanakan dengan cara pembentukan kelompok menjadikan siswa aktif dalam diskusi membuat soal, jika terdapat siswa yang mengalami kesulitan, teman dalam satu kelompok akan memberikan bantuan terhadap teman sekelompoknya. Ketika membuat soal beserta jawabannya siswa memperoleh pemahaman yang lebih mantap

Respon siswa terhadap penerapan pembelajaran pengajuan masalah pada operasi hitung bilangan bulat dalam penelitian ini sangat positif. Hal ini ditunjukkan dari 
hasil angket. Umumnya mereka dapat lebih mudah memahami operasi hitung bilangan bulat setelah membuat soal dan menggunakan papan magnetik. Respon positif lainnya yang ditunjukkan siswa dari hasil angket yaitu mereka menjadi belajar bekerja sama karena hal itu sangat diperlukan saat membuat soal operasi hitung bilangan bulat bersama kelompoknya. Selain itu hasil respon siswa juga menyatakan bahwa pembelajaran operasi hitung bilangan bulat dengan pengajuan masalah dibantu dengan media papan magnetik sangat menarik.

Bagi peneliti lain yang akan menindaklanjuti penelitian ini disarankan untuk mengurangi kelemahan-kelemahan dalam penelitian ini. Peneliti lain harus memiliki keahlian khusus terutama dalam mengarahkan siswa untuk membuat soal. Jika ingin melakukan penelitian menggunakan pembelajaran pengajuan masalah, peneliti lain juga harus merencanakan dengan matang agar waktu dalam pembuatan soal maupun dalam memeriksa soal dan hasil jawaban bisa mencukupi sesuai dengan waktu yang disediakan. Kepada para guru yang berada di SDN Bangsal 4 atau di sekolah lainnya dapat menerapkan pembelajaran pengajuan masalah dalam proses belajar mengajar dan bisa digunakan pada materi lainnya.

\section{DAFTAR PUSTAKA}

Akay, H and Boz, N. (2010). The Effect of Problem Posing Oriented Analyses-II Course on the Attitudes toward Mathematics and Mathematics SelfEfficacy of Elementary Prospective Mathematics Teachers. Australian Journal of Teacher Education. 35 (1).59-75.

Amri, S. (2013). Pengembangan \& Model Pembelajaran Dalam Kurikulum 2013. Jakarta: PT. Prestasi Pustakarya.

Bonotto, C. (2010). Engaging Students in Mathematical Modelling and Problem Posing Activities. Journal of Mathematical Modelling and Application, 1 (3), 18-32.

Christou, et al. (2005). An Empirical Taxonomy of problem posing processes. ZDM. 37 (3), 149 158.

Daryanto. (2016). Media Pembelajaran Perannya Sangat Penting Dalam Mencapai Tujuan Pembelajaran. Yogyakarta: Gava Media

Heruman. (2007). Model Pembelajaran Matematika. Bandung: PT. Remaja Rosdakarya.

Ompusunggu, V.D.K. (2014). Peningkatan Kemampuan Pemahaman Matematik dan Sikap Positif Terhadap Matematika Siswa Smp Nasrani 2 Medan Melalui Pendekatan Problem Posing. Saintech, 06 (04), 93-105.

Muhsetyo, et al. (2014). Pembelajaran Matematika SD. Jakarta: Universitas Terbuka.
Silver, E.A. (1994). On matematical problem posing. For the Learning of Mathematics, 14(1), 19-28.

Siswono, T.Y.E. (1999). Metode Pemberian Tugas Pengajuan Soal (Problem Posing) dalam Pembelajaran Matematika Pokok Bahasan Perbandingan di MTS Negeri Rungkut Surabaya. (Tesis magister pendidikan tidak dipublikasikan): PPs Unesa Surabaya.

Siswono, T.Y.E. (2000). Pengajuan Soal (Problem Posing) oleh Siswa dalam Pembelajaran Geometri di SLTP. Makalah disajikan pada Seminar Nasional Matematika "Peran Matematika Memasuki Milenium III di ITS Surabaya tanggal 2 Nopember 2000.

Siswono, T.Y.E. (2005). Upaya Meningkatkan Kemampuan Berpikir Kreatif Siswa melalui Pengajuan Masalah. Jurnal Pendidikan Matematika dan Sains, (1), 1-9.

Siswono, T.Y.E. (2008). Model Pembelajaran Matematika Berbasis Pengajuan dan Pemecahan Masalah Untuk Meningkatkan Kemampuan Berpikir Kreatif. Surabaya: Unesa University Press.

Slameto. (2015). Belajar \& Faktor-Faktor Yang Mempengaruhinya. Jakarta: PT. Rineka Cipta.

Thobroni, M \& Mustofa, A. (2012). Belajar dan Pembelajaran; Pengembangan Wacana dan Praktik Pembelajaran dalam Pembangunan Nasional. Jogjakarta: Ar-Ruzz Media.

Walle, V.d J. (2006). Sekolah Dasar dan Menengah: Matematika Pengembangan dan Pengajaran Jilid 1. Jakarta: Erlangga.

Walkington, C \& Bernacki, M. (2015). Students authoring personalized "algebra stories": Problem-posing in the context of out-of-school interests. Journal of Mathematical Behavior, 40 (2015), 171-191. 